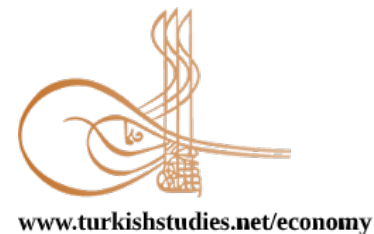

Turkish Studies - Economics, Finance, Politics

eISSN: 2667-5625

Research Article / Araştırma Makalesi

\title{
Dış Ticarette Antrepoların Güvenli ve Etkin Yönetilmesi Kapsamında Kamera Sistemi Uygulamaları
}

\author{
Camera System Applications Within the Scope of Safe and Effective Management of Bonded \\ Warehouse in Foreign Trade
}

\author{
Murat Arslandere ${ }^{*}$ - Ahmet Alper Sayın ${ }^{* *}$
}

\begin{abstract}
Foreign trade is regarded as an indispensable dynamic for today's economies. In this context, attention is paid to the quality, cost and security elements when foreign trade operations are carried out in an increasing global competition environment. All factors which affect these elements directly and indirectly are being tried to be carefully executed and developed. In this context, one of the important elements of foreign trade is bonded warehouse. While operations are performing in bonded-warehouses, there is a necessity to give attention to security efforts for avoiding the occurrence of illegal transactions, illegal goods, theft etc.. At this point, the position of the camera systems must be carefully assessed. In recent years, the implementation of camera systems in bonded warehouses, has been made compulsory within certain standards with the changes in the regulations in Turkey. In this study, in order to explain the effects of these camera system applications to warehouses and foreign trade, in-depth interview and content analysis techniques were used as qualitative research techniques. In-depth interviews were made with Mersin Customs Warehouse Association, and also content analysis was carried out in the official regulations of the state on the subject and findings were shared. It has been observed that this new camera system application provides great support to the security element in the bonded warehouse sector. Although the system will bring a burden of installation cost to the bonded warehouses, it will contribute positively to the foreign trade sector in terms of warehouse transactions in a safer environment. Although there are researches on the establishment and functionality of bonded warehouses, lack of study on issues related to camera systems in the context of safety constitutes the originality of tihs study and will contribute to the literature in this direction.
\end{abstract}

Structured Abstract: Introduction and Purpose of the Study: Foreign trade is regarded as an indispensable dynamic for today's economies. In this context, attention is paid to the quality, cost and security elements when foreign trade operations are carried out in an increasing global competition environment. All factors which affect these elements directly and indirectly are being tried to be carefully

\footnotetext{
* Dr.Öğr.Üyesi, Karamanoğlu Mehmetbey Üniversitesi, Uygulamalı Bilimler Yüksekokulu Asst. Prof. Dr,, Karamanoğlu Mehmetbey University, School of Applied Sciences ORCID 0000-0002-0069-9275 muratarslandere01@gmail.com

** Dr.Öğr.Üyesi, Karamanoğlu Mehmetbey Üniversitesi, Uygulamalı Bilimler Yüksekokulu Asst. Prof. Dr, Karamanoğlu Mehmetbey University, School of Applied Sciences ORCID 0000-0002-2086-6763 ahmetalpersayin@kmu.edu.tr Cite as/ Atıf: Arslandere, M., Sayın, A. A. (2020). Dış ticarette antrepoların güvenli ve etkin yönetilmesi kapsamında kamera sistemi uygulamalar1. Turkish Studies - Economy, 15(2), 749-766. https://dx.doi.org/10.29228/TurkishStudies.41603

Received/Geliş: 04 February/Şubat 2020

Accepted/Kabul: 20 June/Haziran 2020

Copyright (C INTAC LTD, Turkey

Checked by plagiarism software

Published/Yayın: 25 June/Haziran 2020

CC BY-NC 4.0
} 
executed and developed. In this context, one of the important elements of foreign trade is bonded warehouse. While operations are performing in bonded-warehouses, there is a necessity to give attention to security efforts for avoiding the occurrence of illegal transactions, illegal goods, theft etc.. At this point, the position of the camera systems must be carefully assessed. In recent years, the implementation of camera systems in bonded warehouses, has been made compulsory within certain standards with the changes in the regulations in Turkey. In this study, it is aimed to explain the effects of these camera system applications on bonded warehouses and foreign trade. Although there are researches on the establishment and functionality of bonded warehouses, lack of study on issues related to camera systems in the context of safety constitutes the originality of this study and it will contribute to the literature in this direction.

Method: In this study, in order to explain the effects of these camera system applications on warehouses and foreign trade, in-depth interview and content analysis techniques were used as qualitative research techniques. In-depth interviews were made with Mersin Customs Warehouse Association, and also content analysis was carried out on official regulations of the Turkey on the subject and findings were shared.

Findings and Discussion: Within the scope of the findings of this study, it can be easily said that the camera system application has a high level of support for security, based on the content analysis conducted on the current customs legislation regulations related to camera systems, as well as the information received from Mersin Customs Warehouse Association, which was interviewed through in-depth interview method. Technically remarkable features of the system are; it requires installation without blind spots and provides control to critical points with FULL HD (1080P) and at least HD (720P) camera with high quality image to other locations, it provides backward traceability with one year retroactive recording feature, videos can be analyzed in desired criteria and provide alarm feature for unusual situations with intelligent video analysis, it is able to provide control not only with the images but also with the sound with the image synchronous sound recording feature. The system has provided benefits to warehouse businesses. Especially increased security at goods acceptance points, and designing the system in a way that there is no blind spot contributed to preventing suspicions and possibilities of theft, corruption etc.. Accountability and investigation in extraordinary situations have become easier at the point of having the possibility of querying backwards with higher resolution than the old regulation. In case of any external intervention and sabotage, a continuous security factor has emerged thanks to the camera recording 24/7 in all conditions and generating alarms and notifying the relevant people. In addition, the element of being under surveillance 24/7 with the application of the camera system has contributed to the issue that employees are kept under control. So employees paying more attention to work safety, and in general, it indirectly supported to their general performance. In general, companies' level of trust of warehouse sector have increased which operating in the foreign trade sector. There were also disadvantages that the system brought to warehouse operations. The establishment of the camera system application included in the legislation brought a burden on businesses at financial point (on average, between 60 thousand USD and 200 thousand USD depending on the size of the warehouse). This camera system can not be provided from Turkey, so it is imported from abroad, and the absence of a large number of firms making this import caused high prices and increased the cost of establishment. The aforementioned cost increasing led to a direct increase in fixed costs. In the process of getting the system to work with full efficiency during the installation, some integrative and technical problems were experienced in the first stage.

Conclusion and Suggestions: This study will contribute to the literature, since there is no study related to camera systems in bonded warehouse sector in the literature. In foreign trade security issue is very important factor for business. This new camera system supported the security issue, thanks to increasing the measures taken to prevent theft incidents, illegal transactions, illegal products within the scope of storage and shipping operations in bonded warehouses. Due to providing the information about the benefits, disadvantages and the effects of this system on foreign trade, this study will contribute to the businesses and business candidates in the foreign trade sector. In this way, it has positively contributed to the perception of the security of the professionals in the foreign trade sector or candidates to become professionals about transactions in the bonded warehouses. In the light of these information, businesses will have the opportunity to conduct their foreign trade operations more efficiently based on some criteria like time and cost. In this case, it is thought that it will have a positive impact on foreign trade volume. The only disadvantage of the system is the installation cost of the camera system to the bonded warehouse business. Firstly this cost will be reflected to foreign trade companies, then it will be reflected from foreign trade companies to the end users. In addition, future studies' examination of the security factors other than the camera systems in the bonded warehouses will enable a more in-depth analysis of the issue. As a result, given the fact that Turkey's

Turkish Studies - Economy, 15(2) 
foreign trade volume has increased significantly in recent years, the necessity of high quality and secure bonded warehouse systems has become essential. Therefore, this taken step is in a very important position in terms of being a great security guarantee for bonded warehouses for the future.

Keywords: International Trade, Bonded Warehouse, Camera Systems, Security, Efficiency

Öz: Dış ticaret günümüz ekonomileri için vazgeçilmez bir dinamik olarak değerlendirilmektedir. Bu bağlamda artan küresel rekabet ortamında dış ticaret operasyonları yürütülürken kalite, maliyet ve güvenlik unsurlarına azami dikkat edilmektedir. Bu unsurları doğrudan ve dolaylı yönden etkileyen bütün işler de özenle yürütülmeye ve geliştirilmeye çalışılmaktadır. Bu bağlamda dış ticarette önemli bir konumu olan ve üzerinde dikkatle durulması gereken donelerden biri de antrepolardır. Antrepolarda işlemler gerçekleştirilirken yasa dışı işlemler, kaçak ürünler, hırsızlık vb. olayların olmasını engelleme noktasında, güvenlik sağlama çabaları ve işlemlerine yüksek oranda önem verilmesi gereklidir. Bu açıdan kamera sistemlerinin konumu özenle değerlendirilmesi gereken bir konudur. Türkiye'de son y1llarda yapılan yönetmelik değişiklikleri ile antrepolarda kamera sistemleri uygulanması belirli standartlar dahilinde zorunlu hale getirilmiştir. $\mathrm{Bu}$ çalışmada sözkonusu kamera sistemi uygulamalarının antrepolara ve dış ticarete etkilerini açıklamak için, nitel bilimsel araştırma tekniği olarak derinlemesine mülakat ve içerik analizi tekniklerinden faydalanılmıştır. Mersin Gümrüklü Antrepocular Derneği ile derinlemesine mülakat yapılmış, buna ilave olarak konu ile ilgili devletin resmi yönetmelikleri incelenerek içerik analizi gerçekleştirilmiş ve bulguları paylaşılmıştır. Sözkonusu yeni kamera sistemi uygulamasının antrepo sektöründe güvenlik unsuruna büyük destek verdiği görülmüştür. Sistemin antrepolara getireceği kurulum maliyeti dezavantajı olsa da, daha güvenli bir ortamda antrepo işlemlerinin gerçekleşecek olması yönüyle diş ticaret sektörüne olumlu katkı sağlayacaktır. Literatürde antrepoların kurulması ve işlevselliği ile ilgili araştırmalar olmasına karşın, güvenlik bağlamında kamera sistemleri ile ilgili çalışma yapılmaması, araştırmanın özgünlügünü oluşturmaktadır ve bu doğrultuda literatüre önemli katkı sağlayacaktır.

Anahtar Kelimeler: Uluslararası Ticaret, Antrepo, Kamera Sistemleri, Güvenlik, Verimlilik

\section{Giriş}

Günümüzde; küreselleşmenin etkileri, küresel bütünleşme kavramları ile birlikte; rekabet, iç ticaretin karmaşık baskısı, birçok firma için dış ticaret faaliyetleri ve bu faaliyetlerin öneminin artmasına neden olmaktadır (Ak, 2019). Sağlıklı bir dış ticaret faaliyetinin en önemli yönü, mal ve hizmetlerin sağlıklı bir şekilde doğru lojistik uygulamalarla aktarılmasıdır. Bu noktada, lojistik uygulamalarının tüm yönlerinin etkisi giderek artmakta ve tüm lojistik maliyetlerinin yaklaşık \% 40'inı oluşturan depolama faaliyetleri stratejik bir öneme sahip olmaktadır.

Bir ülkeye ithalat veya ihracat işlemlerinde, lojistik, üretim, depolama, denetim ve vergilendirme unsurlarına destek olması yönünden antrepoların önemli bir konumu bulunmaktadır. Ülkeler, iç ekonomik sistemlerin dengesini korumak ve yerli üretimi desteklemek için ithal ürünlerden bazı vergiler almaktadırlar. Ayrıca, ithalat ve ihracat için bazı kriterler geliştirmektedir. $\mathrm{Bu}$ düzenlemeler geçmişten günümüze ülkelere göre farkl1l1k gösterse de, bugün gümrük birliği gibi bazı girişimler ışı̆̆ında bir birlik oluşturmak istenmektedir. Bu süreçte yasal mevzuat üzerinde çalışılmasına rağmen, bu işlemlerde antrepolar önemli bir rol oynamaktadır.

Ülkeler arasındaki iletişim noktasında engellerin azalması veya Serbest Ticaret Anlaşmaları gibi uygulamalar nedeniyle antrepo operasyonlarının verimliliğinin artırılmasına yönelik ilgi artmaktadır (Park vd., 2008: 451). Bu verimli uygulamaların gerçekleşebilmesi, en başta antrepolarda güvenliğin sağlanabilmesi ile mümkün olacaktır. Geçmişten günümüze kadar antrepolarla ilgili yaşanan en önemli sorunların başında, güvenlik problemi gelmektedir. Bu sorun sadece doğrudan antrepo üzerinden ticaret yapan işletmeleri değil, aynı zamanda antrepo aracılığıyla yapılan ticaretten dolaylı olarak da yararlanan tüm kamu sektörünü etkilemektedir. Çünkü yaşanan güvenlik sorunları neticesinde, yüklü miktarda mal sevkiyatı yapan işletmelere, 
ürünlerin hırsılık, kayıp olma gibi nedenlerden dolayı ciddi oranda maliyet yükü getirmektedir. Ayrıca kaçakçılık da üzerinden önemle durulması gereken bir konu olarak karşımıza çıkmaktadır.

Sektörde antrepolarla ilgili birçok sistem çalışması yapılmasına rağmen, ürünlerin depolanması esnasında güvenliğinin sağlanması konusunda yeterince ve etkili uygulamalar yapılmadığı görülmüştür. Ayrıca akademik çalışmalarda da, antrepoların kurulması ve işlevselliği ile ilgili araştırmalar olmasına karşın, güvenlik bağlamında kameralarla ile ilgili çalışma yapılmaması, araştırmamızın özgünlüğünü oluşturmaktadır. Çalışmanın bu doğrultuda literatüre önemli katkı sağlayacağı değerlendirilmektedir.

\section{Dış Ticarette Antrepolar ve Çeşitleri}

Antrepolar, ilgili ülkenin politik sınırları içinde yer alan ve gümrük sınırları dışında bulunan ve bir çeşit depo görevi gören özel yerlerdir. Bu nedenle antrepolarda depolanan mallardan gümrük vergisi alınmaz. Malların nihai ithalatı sırasında gümrük idarelerine başvurulduğunda mali yükümlülükler yerine getirilir (Koban \&Keser, 2007).

Gümrük antrepoları; genel ve özel antrepo olmak üzere ikiye ayrılmaktadır. Uygulama esnasında genel antrepolar; (A), (B) ve (F) tiplerinden oluşmakta ve özel antrepoların; (C), (D) ve (E) tipleri bulunmaktadır.

\subsection{Genel Antrepolar}

Herkes tarafından kullanılabilen gümrük antrepolarıdır. (A), (B) ve (F) olmak üzere üç ayrı tipi şekli bulunmaktadır.

A Tipi Antrepo; İşletmecinin stok kayıtlarını tuttuğu ve depolanan malda herhangi bir eksiklik olması durumunda gümrük vergilerinin ödenmesinden sorumlu genel antrepo türüdür.

B Tipi Antrepo; depodan gelen kişi; Gümrük Kanununun 97'nci maddesinin birinci fikrasında belirtilen kullanıcının sorumlu olduğu antrepo beyanı kullanıcısı tarafından sağlanan genel antrepo türüdür. Antrepo operatörünün sorumluluğu sınırlıdır. Depo operatörü sadece depoları kiralar. Antrepo stok kayıtları tutulmadığı için beyan ve belgeler gümrük kontrolünün esasidir.

F Tipi Antrepo; Gümrük idareleri tarafından işletilen genel antrepo türüdür. Serbest olmayan hareketin sergileneceği sergiler de özel antrepo olarak kabul edilir.

\section{2. Özel Antrepolar}

Sadece antrepo operatörüne ait malların yerleştirilmesi için kurulmuş bir gümrük antreposudur. (C), (D) ve (E) tipleri bulunmaktadır.

C Tipi Antrepo; Operatör ve kullanıcı aynı kişi ve aynı zamanda antrepoya gelen kişiden bu kişinin sorumlu olduğu özel antrepo tipidir.

D Tipi Antrepo; Operatör ve kullanıcı aynı kişi ve aynı zamanda Gümrük Kanunu'nun 104. maddesinin üçüncü fikrasının uygulandığı özel antrepo tipidir.

E Tipi Antrepo; sahibinin ve kullanıcısının aynı kişi olduğu özel gümrüklü antrepo tipidir. Gümrük Kanununun 93 üncü maddesinin 4. fikrasına göre depolama yerinin antrepo isimlendirildiği, depo yeri olmasa bile depo rejimi hükümleri uygulandığ 1 antrepo tipidir (Varol, 2009: 12).

\section{Antrepoların Önemi}

Gümrüklere gelen ticari eşyanın konulduğu ve korunduğu yer olan antrepoların dış ticaretteki önemi oldukça büyüktür. Antrepodaki ürünler resmi olarak inceleme ile birlikte korunmakta ve sahibinin kurum veya tüzel kişilik olma zorunluluğu bulunmaktadır. Ayrıca Gümrük Müsteşarlığı iznine binaen bir gümrük idaresine bağlı şekilde işletilmektedir. Antrepodaki 
ithalat ve ihracat amaçlı mallar piyasaya sürülünceye kadar devlet denetimi altında bulunmaktadır. İçine salt ulusallaşmamış ithal ürünler ile ihracat amaçlı ürünlerin konulabileceği alanlar olan antrepolar, dış ticarette önemi yüksek konumda bulunmaktadır. Antrepolar;

- Vergileri (KDV, gümrük vergisi, vb.) ertelemek amaciyla kullanılabilmektedir.

- Depolamanın yanında ürünün niteliği değiştirmeden ön/son montaj, basit îmalat, mal bölme, bakım-onarım, yeniden paketleme, sıralama, vb. işlemler yapılabilir.

- Transit (sevk ve kabul) maksatlı kullanılır (Tanyaş \&Baskak, 2012: 2).

Bu unsurlar dış ticarete katk1 sağlayarak sürecin ilerlemesinde önem arz etmektedir.

Türkiye gümrük bölgesine, karayolu, hava, deniz ve demiryolu taşıtlarının giriş ve çıkışları denetim altında yapılmaktadır. Gümrük bölgesine getirilen ticari eşyalar için önceden açıklamalı bir şekilde bir özet beyan verilmektedir. Fakat sürekli hareket halinde olan havada ya da karasuları alanında ilerleyen taşıtlardaki ticari unsurlar da böyle bir beyannameye gerek yoktur. Bu bölgelere getirilen eşyalar için beyan, kanunda belirtilen kişiler tarafından sunulmaktadır. Bu kişiler, eşyanın gümrük alanına götürülmesi sorumluluğunu alan taşıyıcı, ya da bunlar namına hareket eden kişiler veya yetkili olan gümrüğe eşyayı sunabilen veya sunulmasını sağlayan şahıslar ya da tüm bu şahısların yetkili temsilcileri olabilmektedir.

Gümrük bölgesine gelen eşyalar buraya getirildikten sonra gümrük idaresinin uygun gördüğü bir yere taşınacaktır. Eşyanın aktarılması ve boşaltılması gümrük idaresinin uygun gördügü yerlerde ve yine idarenin izni ile gerçekleşecektir. Eşya gümrük bölgesine girdikten sonra serbest dolaşım durumu ve gümrük statüleri netleşinceye kadar, serbest dolaşım altında bulunmayan eşya gümrük statüsü farklılaşıncaya kadar veyahut serbest bölgeye geçinceye kadar veya imha edilinceye ya da ihraç edilinceye kadar gümrük idaresinin gözetimi altında kalması zorunludur. Türkiye gümrük sahası içine giren ve çıkan ticari eşyalar ihraç ya da ithal edilene kadar bu gümrük sahası içindeki kurallar çerçevesinde işlem görmekte ve buradaki yönetime tabi olmaktadır (Coşgun, 2011: 377). Hem bu işleyişteki olası aksamaların bertaraf edilmesi hem de genel itibariyle malzemenin alıcıya veya müşteriye ulaşması noktasında uygulamaların etkin yönetilmesi çok elzemdir. Antrepoların bu süreç içinde lojistik, üretim, denetim konularında destek olmasından mütevellit önemli bir unsur olması hasebiyle, üzerinde dikkatle durulması ve verimli şekilde yönetilmesi gerekmektedir.

İthalat vergisi ödemek istemeyen firmalar malların tamamı ülkelerine giriş yaptıktan sonra antrepoya yerleştirirler. Böylece vergi ödemek yerine sadece antrepoya ardiye masrafi öderler. Antrepodaki bu mallar başka bir ülkeden satın alınıp getirtilerek fiili olarak satın alınmış olsa da resmi olarak ithal etmiş sayılmaz. Yurt içinde müşteri buldukça sadece antrepodan çekip sattı̆̆ ürün için kısım kısım ithalat vergisi öder. Böylece antrepolar taşıma gibi masrafları erteleme imkânı sağlamaktadır. Ayrıca ithalatçıya, ithalat vergisi, ihraç ve resim gibi masrafları erteleme olanağı da tanımaktadır (MEB, 2011). Subaşı (2009)'a göre antrepo rejimi kapsamında ithal edilen malların ithalat vergi ödemesinin ertelenebilmesi işletmelere büyük avantaj oluşturmaktadır. Antrepoya koyulan ürünler için firma vergi yerine sadece depo masrafını ödemektedir ki bu da ithalatçı firmanın vergiyi ertelemesini sağlamaktadır. Ayrıca işletme antrepodaki malları satıldıkça parti parti vergi ödemesi durumunda gümrük kuralları gereğince ürünleri sınırsız bir şekilde antrepoda kalabilmektedir. Antrepodaki malları olan ithalatçı firmalar diledikleri gibi burada mallarını muhafaza edebilirler ya da istedikleri takdirde ve miktarda ürünlerini serbest dolaşıma sokabilmektedirler.

Antrepolar dış ticarette ürünlerin, hammaddelerinin de aynı şekilde ithal edilmesinde düşük vergi ve KDV ödemeden malların muhafazası nedeniyle teşvik edici bir özelliğe sahiptir. Böylece ihracatçı firmaların rekabet gücü artmakta ve maliyet açısından olumlu sonuçlarla karşılaştıklarından dolayı daha fazla ihracat gerçekleştirerek gelirlerini arttırmaktadırlar. Ayrıca antrepolar ürünlerin yurt dışı piyasada pazara sunulmasında hız, masraf, zaman bakımından 
firmaya yarar sağlamaktadır ki ihraç edilen mallar ihraç edilecek ülkelere yakın ise mesafe ve maliyet açısından tasarruf sağlayacaktır. Bunlara ilave olarak antrepolar, ticari eşyaların koyulduğu ve muhafaza edildiği yerler dışında da ülkeye kanunsuz olarak giren malların kanuni işlemlerinin tamamlamasına kadar tutulması gerektiği lokasyonlardır. Bu kanunsuz giren eşyalar belirli bir süre sonunda satılarak paraya dönüştürülmekte ve bu satıştan belli bir oranda antrepoya gelir sağlanmaktadır.

Antrepoların mevcutta bulunduğu ülkelerde ticaret hacmi daha yüksek olmaktadır. Bu ticari eşyalar ister partiler halinde ister tamamının çıkış işlemleri sözkonusu antrepolardan gerçekleştirilmektedir. Sözkonusu ticari eşyalar müşterileri ile buluşana kadar antrepolarda bekletildiklerinden, ürünlerin sahibi firmalar ürünün kaldığı süre ile doğru oranda antrepo maliyeti öderler. Bu durumda bölge ekonomisine destek sağlamaktadır (Özeroğlu, 2011: 37).

\section{Antrepolarda Güvenlik Kavramı}

Antrepolar ticaret engellerini azaltan, alıcı ülkeyi ve satıcı ülkeyi birbirine bağlayan transit ticareti de sağlayan önemli bir unsur olması sebebiyle, güvenlikle birlikte gerekli teknik altyapıyı ve prosedürleri sağlamış olması şarttır (Guangming, 2016: 403).

Bir depo tarafından gerçekleştirilen fonksiyonlar;

1. Bir kaynaktan gelen malların alınması,

2. Gerekli olana kadar malların saklanması,

3. Gerekli olduğunda malların alınması,

4. Malların uygun kullanıcıya gönderilmesi

şeklindedir (Tompkins \&Smith, 1998). Tüm bu süreçlerin ise etkin ve verimli yönetilmesi için ilk şart güvenlik unsurunun sağlanmış olmasıdır. Ürünlerin alınması esnasında yasaklı ürünlerin sisteme girmesi, saklanması esnasında çalınma riski, sevkiyatı esnasında yine zarar görmesi, çalınması veya yasadışı işlemlerin yapılıyor olmasını bertaraf etme noktasında güvenlik unsurunun önemi had safhadadır.

Ürünün depo içerisindeki güvenliği her şeyden önemlidir. Depo, sorumluluğu altındaki tüm ürünlerin, üçüncü şahıs bir yüklenici olarak başka şirketlere ait olup olmadıklarına bakılmaksızın bütünlügünden sorumludur. Bu iyi bir depolama sistemi ile kapalı devre televizyon (CCTV) sistemlerinin titiz ve dikkatle kullanımı ile elde edilebilir. Yükleme rihtımları ve platformları en hassas bölgeler olma eğilimi gösterir. Bu yerler hırsızların çalıntı malları, örneğin bir yabancıyla, örneğin bir şoförle ortaklaşa çıkarılması çok kolay yerlerdir. Güvenlik sistemleri, tesisleri insanlara karşı sızmaktan korumak için tasarlanmaya meyillidir, ancak birçok hırsızlık içeriden yapılabilmektedir. Depo boyunca stratejik noktalarda kapalı devre televizyon önemli bir caydırıcı unsurdur, ancak habersiz denetimlerinde etkili ve çok daha ucuz olacağı unutulmamalıdır. Yükleme bölmeleriyle ilgili olarak, ortak bir görüş, bu yerlerin çalışan park alanlarından ayrılması ve bu sayede depodan öğeleri çıkarmanın çok daha zor hale gelmesidir. Yönetim tarafından rastgele başlatılan ve giriş ve çıkışta yapılan aramalar da çok etkilidir. Ürün güvenliği yanında aynı zamanda verilerin korunması da önemlidir. Dahili olarak bu, farklı erişim seviyeleri için şifre koruması ve harici koruma için de güvenlik duvarları kullanılarak yapılabilir. Veriler günlük olarak yedeklenmeli ve yedek dosyalar site dışında saklanmalıdır (Richards, 2017: 127).

Tompkins \&Smith (1998)'e göre başarılı bir depolama için gereklilikler profesyonellik, müşteri bilinci, ölçme, operasyon planlama, lojistik ağ, üçüncü taraf, hız, çeşitlilik, esneklik, belirsizlik, entegrasyon, envanter yönetimi, alan kullanımı, kat hizmetleri, sipariş toplama, takım temelli sürekli iyileştirme, sürekli akış, depo yönetim sistemleri, lojistik toplam maliyeti ve liderlik unsurlarının optimize edilmesi ile ilişkilidir. Tüm bu 20 koşulun yerine getirilmesi ise en başta 
depo güvenliğinin sağlanmış olmasına bağlı olup, bu doğrultuda önlemler alınıp, gereksinimler karşılanarak ve eylem planları hazırlanarak uygulamaya geçilmelidir.

Depo tasarımının amaçları altı unsuru kapsamaktadır ve bu unsurlardan biri de güvenlikkoruma unsurudur. Diğer beş unsuru ise kübik kapasite kullanımı, mekanize sistemler, verimlilik, üretkenlik ve kaynaklar olarak değerlendirilmiştir.

Depolama esnasında malların güvenlik ve korunması üzerinden özenle durulması gereken unsurların başında gelmektedir. Bu noktada;

- Yanıcı, patlayıcı ve okside olması muhtemel tehlike unsuru içeren mallar ayrılmalıdır.

- Değeri yüksek ve ebat olarak daha küçük olan mallar için özel güvenlik önlemi alınan ve kolayca erişilemeyen bir alan yapılmalıdır. (Örnek: Belirli sıraların en üstteki rafların kullanımı ve güvenlik kamerası kullanılması).

- Is1 ve soğutma ile ilgili mallar belirtilmeli ve dizayn ona göre planlanmalıdır.

- Depoda koruma ve muhafaza edilen ürünlerden ağır ve hafif olanlar belirlenmeli, çalışanlar bu konuda uyarılmalı ve kırılması muhtemel malların üzerine ağır malların koyulmamasına ve istiflenmemesine özen gösterilmelidir

- Tekil halleri ile tehlike arz etmeyen, lakin buharları birbirleri ile etkileşime girdiğinde patlama riski oluşturabilecek ürünler ayrıca konumlandırılarak birbirinden ayrılmalıdır.

- İlave olarak depo giriş çıkışları, depo iç mekânı da etkin biri sistemle kontrol altında tutulması, güvenlik unsuru had safhada sağlanıp, hırsızlık kaçakçılık vb. yasa dış1 işlemlerin önüne geçilmelisi unsurları da göz önünde tutulup depo tasarımı yapılmalıdır (Acar \&Çakmak, 2013: 199; Hopbaoğlu, 2009: 113-114).

Depolar tasarlanırlarken temel olarak üzerinde durulan konulardan biri de kübik kapasite kullanımının optimum seviyeye çıkarılmasıdır. Hızlı hareket etmekte olan ürünler için konforlu bir ulaşımın sağlanması noktasında geniş koridorların bulunması, yavaş hareket etmekte olan eşyalar için ise koridorların dar dizaynı ve yüksek raf dizaynlarının değerlendirilmesi zaruridir. Depolama stratejisinin, depodaki insan gücü ve elleçleme masraflarının minimize edilecek ve depo hacminin verimli kullanımı olacak şekilde belirlenmesi, tasarım verimliliğinin iki boyutunu teşkil etmektedir. $\mathrm{Bu}$ sistemler standart işlemlerin gerçekleştiği depolar için uygun olurken her depo için etkili olamamaktadır. Otomasyon sistemlerine karar vermeden önce tüm riskler tüm boyutlarıly birlikte ele alınarak değerlendirmeler yapılmalıdır. Bu risklerden bazıları, teknolojik değişimlerle birlikte mevcutta kurulacak sistemin demode olabilme durumu, pazardaki değişiklikler doğrultusunda oluşan müşteri miktarında meydana gelebilecek değişiklikler ve yatırımın kendinin amorti etme durumu şeklinde belirtilebilir. Bu aşamada depodaki işlemlerin gerçekleşmesi esnasında işlemler oluruna birakılmamalı, en ince detayına kadar incelenmeli ve firmalar üretimi maksimuma çıkarabilecek ve maliyetlerini minimize edecek şekilde standartlar belirlenmelidir. Üretkenliğin gözlemlenip ölçüleceği kaynaklar kapsamında; ekipmanlar, tesisler, insan gücü, enerji ve finansal yatırımlar yer almaktadır. Depo kaynakları üretkenliğinin gerçekleşme durumu kontrol aşamasında gözetlenmesi gereken unsurlar; kabul, depolama, yerleştirme, sipariş toplama, ikmal, kontrol, markalama, paketleme, siparişleri birleştirme, sevk alanına alma, işçilik ve sevk işlevleridir. Bütün bu tasarım unsurlarının başarılı olması, güvenlik unsuruna dikkat edilmesine bağlıdır (Hopbaoğlu, 2009: 113-114).

Depo güvenliğindeki önemli bir sorun, gerekli olan güvenlik seviyesini belirleme ile ilgilidir. Tüm tesis güvenli ise, koruma ve kapılara olan ihtiyaç sınırlıdır. Erişimi ve çıkışı kontrol etmek, park alanlarını binanın yakın çevresinden uzak tutmak ve binaya nüfuz etmesi zor olan bir yapıyı tasarlamak güvenlik maliyetini sınırlamaktadır. Alarm sistemleri caydırıcı olarak yararlıdır, ancak profesyonel hırsız onları da baypas edebilir (Tompkins \&Smith, 1998). İşte bu noktada kamera sistemlerinin kullanılması büyük önem arz etmektedir. 


\section{Materyal ve Metot}

\subsection{Araştırmanın Amacı}

Bu çalışmada dış ticarette önemli bir rejim olan antrepo rejiminin, güvenli bir şekilde işlemesine destek olması noktasında, teknolojik yönü gelişmiş ve güvenlik seviyesi arttırılmış olan ve Türkiye'de yeni bir uygulama olarak karşımıza çıkan, antrepolarda kamera sistemi uygulaması ele alınmıştır. $\mathrm{Bu}$ kapsamda gümrük yönetmelikleriyle belirli standartlar dahilinde uygulaması zorunlu hale getirilmiş kamera sisteminin antrepoların etkin ve güvenli yönetilmesi kapsamında fayda ve dezavantajlarını ortaya koyabilmek amaçlanmıştır. Ayrıca antrepolarda uygulanmakta olan bu yeni kamera sistemlerinin işletmelere ve sektöre getirdikleri ortaya konulmaya çalışılmış, ayrıca genel itibariyle dış ticaret piyasasına etkisi de değerlendirme içine alınmaya gayret gösterilmiştir.

\subsection{Yöntem}

$\mathrm{Bu}$ çalışmada nitel bilimsel araştırma tekniği olarak derinlemesine mülakat tekniği kullanılmıştır. Buna ilave olarak yine bir bilimsel araştırma tekniği olan içerik analizi tekniğinden de faydalanılmıştır. Sektörde dernek bazında antrepoların büyük bir bölümünü üyeleri kanalıyla kapsayan Mersin Gümrüklü Antrepocular Derneği ile derinlemesine mülakat yapılmış (Gürbüz \&Şahin, 2018), buna ilave olarak konu ile ilgili devletin resmi gümrük yönetmelikleri incelenerek içerik analizi (Gökçe 2019; Bilgin 2014) gerçekleştirilmiş ve nihayetinde bulguları paylaşılmıştır.

Görüşme türleriyle ilgili literatürde daha çok yapılandırılmış/yarı yapılandırılmış/yapılandırılmamış görüşme şeklinde sınıflandırma yapılmıştır. Yapılandırılmış görüşmede görüşülen kişiden önceden belirlenmiş, standart soruları cevaplaması istenir. Görüşme formunda açık uçlu sorulara pek yer verilmediğinden esneklik ve farklılıklar en aza indirilmiştir. Yapılandırılmamış görüşme ise standartlaştırılmamış, açık uçlu soruların sorulduğu derinlemesine görüşmedir (Puneh 2005: 167). Bu noktadan hareketle çalışmamızda soru formu kullanılmamış ve konunun akışına istinaden açık uçlu sorular yöneltilmiştir. Derinlemesine görüşme, araştırılan konunun bütün boyutlarını kapsayan, daha çok açık uçlu sorularla sorulduğu ve detaylı cevapların alınmasına imkan veren, birebir görüşülerek bilgi toplanmasına imkan veren bir veri toplama tekniğidir. Karşıdaki kişinin duygu, bilgi, tecrübe ve gözlemlerine görüşme yoluyla ulaşılır. Görüşmeyi yapan kişinin bizzat aktif olarak sürece katılımını istemesi özelliğiyle derinlemesine görüşme diğer görüşme türlerinden ayrılır (Johnson 2002: 109). Esasen sadece görüşmeci değil görüşme yapılan kişi de görüşmede aktif olarak rol almaktadır. Derinlemesine görüşmede iki temel aktör vardır. Bunlardan ilki görüşmesi yani araştırmayı yapan kişi, diğeri ise kendisiyle görüşülen, anahtar kişi olarak bilgisine başvurulan kişidir. Derinlemesine görüşme, etkileşimin her iki tarafında bulunan kişilerin karşıllklı ortak çabaları sonucunda bilginin ve anlamın inşa edildiği bir süreçtir (Hostein\&Gubrium 2004: 141). Çok çeşitli ve zengin detaylara sahip bir resmin, o resimle ilgili olan insanlar tarafından, o güne kadar sahip oldukları tecrübeler çerçevesinde, nasıl yorumlandığının öğrenilmesinde derinlemesine görüşme daha işlevseldir. Eğer görüşme hedeflenen biçimde gerçekleştirilebilirse başka türlü elde edilmesi mümkün olmayan verilerin toplanabildiği çok güçlü bir teknik olarak kabul edilebilir.

İçerik analizi, metinlerin anlamlarını kategorilere göre sistematik bir şekilde incelemeye ve çıkarımlar yapmaya dayanan bir araştırma yöntemidir (Gökçe, 2019: 33). İçerik analizindeki ana unsur metinlerden yorum yapmak ve çıarımlarda bulunmaktır (Bilgin, 2014: 1).

Aşağıda Tablo-1 ve Şekil-1'de araştırmanın anakütlesini oluşturan bütün antrepolar, bağlı oldukları gümrük müdürlükleri bazında verilmiştir. Görüldüğü üzere ilk on gümrük müdürlüğü sektördeki toplam antrepoların yarısından fazlasını kapsamaktadır. Gümrükler Genel Müdürlügü resmi verilerine göre Türkiye'de toplamda 1380 adet antrepo faaliyet göstermektedir (Gümrükler Genel Müdürlüğü, 2019). 
Tablo 1: Bağlı Bulundukları Gümrük Müdürlükleri Bazında Türkiye'de Antrepoların Nicel Durumu

\begin{tabular}{|c|c|c|c|}
\hline $\begin{array}{l}\text { Antreponun Bağlı Olduğu Gümrük } \\
\text { Müdürlüğ̈ü }\end{array}$ & Adet & $\begin{array}{l}\text { Antreponun Bağlı Olduğu Gümrük } \\
\text { Müdürlüğ̈̈ }\end{array}$ & Adet \\
\hline Halkalı Gümrük Müd. & 135 & Naklihane Ve Bedelsiz İth. Gümrük Müd. & 5 \\
\hline Dilovasi Gümrük Müd. & 134 & Trabzon Gümrük Müd. & 5 \\
\hline Erenköy Gümrük Müd. & 81 & Kapıkule Gar Gümrük Müd. & 4 \\
\hline İzmir Gümrük Müd. & 68 & Kuşadasi Gümrük Müd. & 4 \\
\hline Ambarlı Gümrük Müd. & 64 & Akıncı Gümrük Müd. & 3 \\
\hline Mersin Gümrük Müd. & 59 & Botaş Gümrük Müd. & 3 \\
\hline Derince Gümrük Müd. & 55 & Dikili Gümrük Müd. & 3 \\
\hline Aliağa Gümrük Müd. & 39 & Giresun Gümrük Müd. & 3 \\
\hline Gebze Gümrük Müd. & 39 & Gürbulak Gümrük Müd. & 3 \\
\hline A.H.L. Yolcu Salonu Gümrük Müd. & 38 & İncirlik Gümrük Müd. & 3 \\
\hline Haydarpaşa Gümrük Müd. & 37 & İzmir Tir Gümrük Müd. & 3 \\
\hline Antalya Havalimani Gümrük Müd. & 34 & Kapikule Yolcu Sal. Gümrük Müd. & 3 \\
\hline Kocaeli Petrokimya Ür. İhtisas Gümrük Md: & 33 & Aksaray Gümrük Müd. & 2 \\
\hline A.H.L. Kargo Gümrük Müd. & 31 & Çeşme Gümrük Müd. & 2 \\
\hline Gemlik Gümrük Müd. & 30 & Cilvegözü Gümrük Müd. & 2 \\
\hline İskenderun Gümrük Müd. & 27 & Denizli Gümrük Müd. & 2 \\
\hline Tekirdağ Gümrük Müd. & 25 & Habur Gümrük Müd. & 2 \\
\hline Ankara Tır Gümrük Müd. & 23 & Hamzabeyli Gümrük Müd. & 2 \\
\hline Karaköy Yolcusalonu Gümrük Müd. & 22 & Hopa Gümrük Müd. & 2 \\
\hline Bursa Gümrük Müd. & 21 & İpsala Gümrük Müd. & 2 \\
\hline İsdemir Gümrük Müdürlüğü (Transit) & 21 & Karabük Gümrük Müd. & 2 \\
\hline A.Menderes Gümrük Müd. & 20 & Kırıkkale O.A.R. Gümrük Müd. & 2 \\
\hline Dalaman Havalimani Gümrük Müd. & 18 & Marmaris Gümrük Müd. & 2 \\
\hline Bandırma Gümrük Müd. & 17 & Rize Gümrük Müd. & 2 \\
\hline Bodrum Gümrük Müd. & 15 & Sarp Gümrük Müd. & 2 \\
\hline Çerkezköy Gümrük Müd. & 15 & Bursa Tekstil İhtisas Gümrük Müd. & 1 \\
\hline Esenboğa Gümrük Müd. & 15 & Dereköy Gümrük Müd. & 1 \\
\hline Kayseri Gümrük Müd. & 15 & Diyarbakir Gümrük Müd. & 1 \\
\hline Samsun Gümrük Müd. & 14 & Ggmtest1 Gümrük Müd. & 1 \\
\hline Adana Gümrük Müd. & 13 & Ggmtest2 Gümrük Müd. & 1 \\
\hline İzmit Gümrük Müd. & 13 & İpekyolu Gümrük Müd. & 1 \\
\hline Sabiha Gökçen Havalimani Gümrük Müd & 13 & İstanbul Deri Serbest Bölge Gümrük Müd. & 1 \\
\hline Mersin Akaryakit Gümrük Müd. & 12 & İzmir Yolcu Salonu Gümrük Müd. & 1 \\
\hline Çanakkale Gümrük Müd. & 11 & Kapıkule Tir Gümrük Müd.. & 1 \\
\hline Karadeniz Ereğli Gümrük Müd. & 11 & Konya Gümrük Müd. & 1 \\
\hline Eskişehir Gümrük Müd. & 10 & Malatya Gümrük Müd. & 1 \\
\hline Yalova Gümrük Müd. & 9 & Muhtest1 Gümrük Müd. & 1 \\
\hline Yeşilköy Otomotiv İhtisas Gümrük Müd. & 9 & Nusaybin Gümrük Müd. & 1 \\
\hline Beylikdüzü Akaryakit Gümrük Müd. & 8 & Ordu Gümrük Müd. & 1 \\
\hline Sakarya Gümrük Müd. & 8 & Pazarkule Gümrük Müd. & 1 \\
\hline Doğubeyazit Gümrük Müd. & 7 & Taşucu Gümrük Müd. & 1 \\
\hline Gaziantep Gümrük Müd. & 7 & Uzunköprü Gümrük Müd. & 1 \\
\hline Manisa Gümrük Müd. & 6 & Van Gümrük Müd. & 1 \\
\hline Mudanya Gümrük Müd. & 6 & Zonguldak Gümrük Müd. & 1 \\
\hline \multirow[t]{2}{*}{ Antalya Gümrük Müd. } & 5 & & \\
\hline & Coplam & & 1380 \\
\hline
\end{tabular}

Kaynak :Yazarlar tarafından Ticaret Bakanlığı Gümrükler Genel Müdürlüğü verileri kullanılarak oluşturulmuștur (Erișim Tarihi : 14-08-2019). 


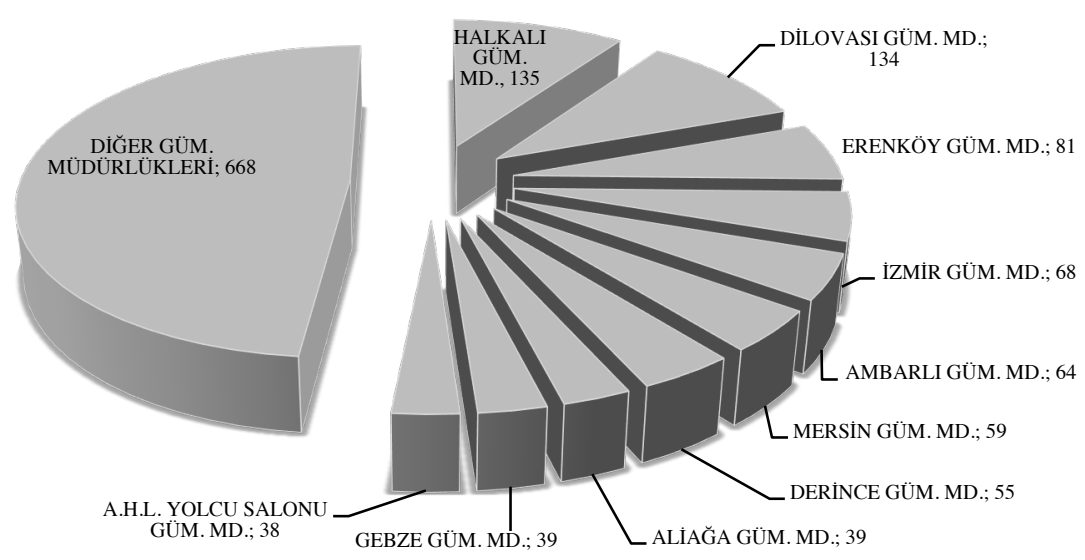

Şekil 1: Bağlı Bulundukları Gümrük Müdürlükleri Bazında Türkiye'de Antrepolar

Kaynak: Yazarlar tarafından Ticaret Bakanlığı Gümrükler Genel Müdürlüğü verileri kullanılarak oluşturulmuştur (Erişim Tarihi: 14-08-2019).

\section{Bulgular}

\subsection{Gümrük Mevzuatı İçerik Analizi Sonucu Bulgular ve Değerlendirme}

Gökçe (2019)'a göre içerik analizinde metinler, anlamları bağlamında kategoriler bazında incelenmeli ve ardından çıkarımlar yapılmalıdır. $\mathrm{Bu}$ doğrultuda antrepolarda kullanılan kamera sistemleri ile ilgili gümrük yönetmelikleri incelenmiş ve 4 ana kategoride çıkarımlar yapılmıştır. Bunlar; kör nokta kalmayacak şekilde kurulum, bir yıl geriye dönük kayıt, akı1lı video analiz ve alarm özelliği, görüntü ile senkron ses kaydı şeklindedir. Aşağıda ilk olarak yönetmeliklere yer verilmiş, ardından içerik analizi sonucu yapılan kategorilere göre çıkarımlar paylaşılmıştır.

Bilindiği üzere, 02.12.2014 tarihli 29193 sayılı Resmi Gazete'de yayımlanan Gümrük Yönetmeliği'nde Değişiklik Yapılmasına Dair Yönetmelik'le birlikte antrepolara teknolojik seviyesi ve güvenlik sağlama düzeyi yüksek kamera sistemi uygulamasına geçilmiştir. Daha sonra ise 31 Ocak 2015 tarihli ve 29253 sayılı Resmi Gazete'de yayımlanan Gümrük Yönetmeliği’nde Değişiklik Yapılmasına Dair Yönetmelikle ise konu ile ilgili bazı unsurlar değiştirilmiş bazı unsurlar eklenmiştir. Gümrük ve Ticaret Bakanlığı tarafından Bölge Müdürlüklerine iletilen yazı kapsamında antrepo işleticilerine kamera sistemlerini kurmaları için süre verilmiştir. Aşağıda tabloda ise yeni ve eski yönetmeliklerin asgari teknik özellikler ve kamera yazılımı kategorilerinin karşılaştırması yer almaktadır. Bu kategoriler ile birlikte genel özellikler kategorisi de içerik analizine tabi tutulmuştur. 2020 y1lı itibariyle sözkonusu son değişiklikler halen güncel konumdadir.

Tablo 2: Antrepolarda Kullanılan Kamera Sistemleri ile İlgili Yönetmeliklerin Karşılaştırılması (Asgari Teknik Özellikler Bazında)

\begin{tabular}{|c|c|}
\hline $\begin{array}{l}2 \text {.12.14 Tarihli 29193 Sayılı Resmi Gazete'de } \\
\text { Yayımlanan }\end{array}$ & $\begin{array}{l}\text { 31.01.15 Tarihli 29253 Sayılı Resmi Gazete'de } \\
\text { Yayımlanan }\end{array}$ \\
\hline nik Özellikler & Asgari Teknik Özellikler \\
\hline $\begin{array}{l}\text { - Kameralar M-JPEG, H.264 veya MX-Peg görüntü } \\
\text { sikıştırma formatlarını desteklemeli, } \\
\text { - Kameralar, 1080P. 720P, D1 veya CIF çözünürlükte } \\
\text { görüntüler elde edebilmeli, } \\
\text { - Kameraların video gösterim ve kayıt hızı MX-Peg veya } \\
\text { H.264 formatında olmalı, } \\
\text { - Kameralar } 3 \text { Megapixel 2048x1536 çözünürlükte en az } 20 \\
\text { fps, } 1 \text { (bir) Megapixel 1280x960 çözünürlükte en az } 20 \text { fps, } \\
\text { VGA 640x480 çözünürlükte en az } 25 \text { fps olmalı veya } \\
\end{array}$ & $\begin{array}{l}\text { - Kameralar, M-JPEG, H.264, MPEG-4 veya MX-Peg } \\
\text { görüntü sıkıştırma formatlarını desteklemeli, } \\
\text { - Kameralar, en az 720P (analog kamera ise D1) } \\
\text { çözünürlükte görüntüler elde edebilmeli, } \\
\text { - Kameralar, en az } 10 \text { (on) fps kayda izin vermeli, } \\
\text { - Kameralar; } \\
\text { *En az Fİ ,2'de } 2.8 \mathrm{~mm}, \text { F.l.ö'de } 4.3 \mathrm{~mm} \text { ayarlanabilir } \\
\text { lense sahip olmalı ve en fazla } 1 / 2,5 " \text { (bir bölü iki virgül } \\
\text { beş inç) CMOS'a sahip olmalı(daha geniş açılı lensler de }\end{array}$ \\
\hline
\end{tabular}


700TVLine çözünürlükte 1080P çözünürlükte, saniyede 30 resim (30 FPS), H.264 video sıkıştırma formatında veya saniyede 25 resim (25FPS) hızında, 720P çözünürlükte MJPEG video sıkıştırma formatında görüntü sağlamalı, - Kameralar;

* En az F.1.6, 4.3mm lens veya 1/ 2,5" (bir bölü iki virgül beş inç) CMOS'a sahip olmalı, Arka plan ışığını dengelemeli, Otomatik beyaz dengelemeli,Görüntü bozukluğunu düzeltmeli, Video sensörü ile hareket algılamalı, Ses artışı algılamalı, Akıllı hareket algılamalı, Darbe ( sabotaj ) algilamal,,

* Kameraların 1şık hassasiyeti gündüz; 0,25 (sıfır virgül yirmi beş)lux veya daha düşük 1șı şartları altında çalışabilecek nitelikte olmalı veya kameranın 1şık gereksinimi 0,6lux@F1.6 veya en düşük parlaklık 0,1lux@F1.2, siyah-beyaz 0.01lux@f1.2) olmal1, * Işık hassasiyeti gece; 0,05 (sıfır virgül sıfır beş) lux veya daha düşükışık şartları altında çalışabilecek nitelikte olmalı, * SD hafiza kartı yuvasına sahip olmalı,

- Kameralar ağ bağlantısı üzerinden ve başka bir bilgisayara veya sunucuya ihtiyaç duymaksızın Ağa Bağlı Depolama Birimine (NAS) veya Ağa Video Kaydedici (NVR) cihazına kayıt yapabilmeli,

- Kameralar operatör kontrolü ile dijital olarak ve motor kullanmaksızın; yatay ve dikey görüș alanındaki herhangi bir bölgenin görüntüsünü seçerek sergileyebilmeli (pan-tilt), - Kamera operatör kontrolü ile dijital olarak ve motor kullanmaksızın canlıveya kayıt görüntülerinde; görüş açısındaki herhangi bir bölgenin görüntüsünü büyütebilmeli (zoom),

- Kameralar, mikrofon ile diş ortamdaki sesleri operatöre iletme ve kaydetme özelliğine sahip olmalı,

- Kameralar, Ethernet bağlantısı üzerinden TCP/IP protokol video çıkışsağlamalı,ve 10 adet kullanıcı atanabilmeli ve kullanıcılara farkliyetkiler atanabilmeli,

- Kamera sistemine aynı anda 8 kullanıcı bağlanabilmeli, - Kamera kullanıcı ve yönetici şifre koruma seviyelerine sahip olmal1,

- Kameralar 3 boyutlu gürültü azaltma özelliğini (MCTF) desteklemeli,

- Kameralar, geniș dinamik aralık (2D WDR) ve arka 1şık bastırma (BLC) özelliklerini desteklemeli,

- Kameralar, video akışında ilgi alanı (ROI) özelliğini desteklemeli, ve gizlilik maskeleme (4 bölge) özelliğini desteklemeli,

- Kameralar, dijital zoom özelliğini desteklemeli,

- Kameralar, video mirror ve flip özelliklerini desteklemeli,

- Kameraların IP, TCP, UDP,http, SMTP, NTP, DDNS, UPnP, FTP, ARP, DHCP, PPPoE, DNS, RTSP, RTCP, Telnet, ONVIF protokollerine entegre desteği olmalı, - Sistem en az beș farklı alıcıya JPEG anlık durum görüntüsü göndermek için elektronik posta hizmeti sağlamalıdır.

Kaynak : 2 Aralık 2014 tarihli 29193 sayılı ve 31 Ocak 2015 tarihli ve 29253 sayılı Resmi Gazetede Yayımlanan Gümrük Yönetmelikleri

\section{kabul edilir),}

*Arka plan ışı̆̆ını dengelemeli,

*Otomatik beyaz dengelemeli,

* Ak1ll hareket algilamalı,

*Darbe (sabotaj) algilamal1,

*Görüntü ile senkronize ses kaydı sağlamalı,

* Gündüz en az Fİ.2 1ş1k hassasiyeti, 1/30 saniye örtücü hız, 50IRE'de 0,3 (sıfır virgül üç) lux veya daha düşük 1şık şartları altında çalışabilecek niteliklerde olmalı,

*Gece en az Fİ.2 1şık hassasiyeti, 1/30 saniye örtücü hız, 50IRE!de 0,05 (sıfır virgül sıfır beș) lux veya daha düşük 1şık şartları altında çalışabilecek niteliklerde olmalı, *Hem gündüz, hem de gece net görüntü verebilmesi için mekanik infrared filtreye sahip olmal1, *SD hafıza kartı yuvasına sahip olmalı, ağ bağlantısıbir nedenden dolayı kesildiğinde üzerine kayıt yapılabilmeli ve en az 64 GB'ye kadar hafiza kartını desteklemeli,

- Kameralar, ağ bağlantısı üzerinden bir kayıt sunucusuna, Ağa Bağlı Depolama Birimine (NAS) veya Ağa Video Kaydedici (NVR) cihazına kayıt yapabilmeli, - Kameralar, görüş açısındaki herhangi bir bölgenin görüntüsünü büyütebilmeli (zoom) veya dijital yakınlaştırma (dijital zoom) ve sonrasında resmin içerisinde gezinme yapabilmeye elverişli olmalı, - Kameralar, mikrofon ile diş ortamdaki sesleri operatöre iletme ve kaydetme özelliğine sahip olmalı,

- Kameralar, ethernet bağlantısı üzerinden TCP/IP protokol video çıkışsağlamalı,

- Kamera sistemine 10 adet kullanıc atanabilmeli ve kullanıc1lara farklıyetkiler tanımlanabilmeli,

- Kamera sistemine aynı anda 8 kullanıcı bağlanabilmeli, - Kamera, kullanıcı ve yönetici șifre koruma seviyelerine sahip olmalı, ve 3 boyutlu gürültü azaltma özelliğini desteklemeli,

- Kameralar, geniş dinamik aralık (WDR-60dB) ve arka 1şık bastırma (BLC) özelliklerini veya akıllı gölge teknolojisinidesteklemeli,

- Kameralar, gizlilik maskeleme (4 bölge) özelliğini desteklemeli, ve dijital zoom özelliğini desteklemeli, - Kameralar, video mirror veya video flip özelliklerini desteklemeli,

- Kameralar veya kayıt sistemlerinin; IPv4'te TCP/IP, UDP, HTTP, SMTP, POP3, NTP, DNS, FTP, ARP, DHCP, RTSP, ONVIF (TAM ÜYE) protokollerine, IPvö'da ise TCP/IP, UDP, HTTP, FTP, SMTP, DNS, ICMPv6, P0P3, NTP, SMTP, ONVIF (TAM ÜYE) protokollerine entegre desteği olmalı,

- Sistem, en az beș farklı alıcıya JPEG anlık durum görüntüsü göndermek için elektronik posta hizmeti sağlamalıdır. 
Tablo 3: Antrepolarda Kullanılan Kamera Sistemleri ile İlgili Yönetmeliklerin Karşılaştırılması (Kamera Yazılımı Bazında)

\subsubsection{Tarihli Ve 29253 Sayılı Resmi Gazete'de} Yayımlanan

\begin{tabular}{l} 
2.12.14 Tarihli 29193 Sayılı Resmi \\
Gazete'de Yayımlanan \\
\hline \multicolumn{1}{c}{ Kamera Yazılımı } \\
\hline Canlı izleme ve video oynatma için dijital zoom \\
özelliğini desteklemeli, \\
- PTZ preset geri çağırma, pan (sağa sola hareket \\
edebilme), tilt (aşağıyukarı hareket edebilme), \\
zoom (uzaklaştıma yakınlaştırma) ve PTZ preset \\
kaydetme işlemleri dahil olmak üzere IP PTZ \\
özelliklerini desteklemeli, \\
- Yazılım, sisteme bağlı tüm kameraların \\
görüntüsünü gerçek zamanlılarak ve kayıt \\
üzerinden sergileme yeteneğine sahip olmalı, \\
- Yazılım, seçilen bir zaman aralığına ait \\
olay/alarmların sorgulamasınıyapabilmeli, \\
- Yazılım, kameralar tarafından tespit edilen \\
hareket alarmlarını sergileme ve operatörü sesli ve \\
görüntülü olarak ikazlama fonksiyonuna sahip \\
olmalı, \\
- Bir alarm/olay tetiklendiğinde tetiklenmiş kanalın \\
görüntüsünü ana monitörde göstermeye \\
ayarlanabilmeli, \\
- Bir olay algılandıktan sonra pre-alarm ve post- \\
alarm kaydını başlatabilmeli, \\
- Yazılım herhangi bir zamanda kameraların \\
kaydettiği görüntüleri eşzamanlı olarak \\
sergileyebilmeli, \\
- Hızlı oynatma için alarm bildirimlerini veri \\
tabanına belgelendirmeli, \\
- Sürekli kayıt, kayıt kapalı, alarm/olay kaydı için \\
bir haftada saatlik bazda zamanlanmış kayıt \\
özelliğini desteklemeli, \\
- Kaydedilmiş videoyu JPEG ve AVI formatlarına \\
dönüştürmeyi desteklemeli, \\
- Canlı erişim sağlayan entegre web hizmetine \\
sahip olmalı, \\
- Yazılım değişik kullanıcı ve gruplar için erişim \\
yetkileri tanımlama ve şifre ile erişim imkanına \\
sahip olmalı, \\
- Yazılım kullanıcıların eylemlerini bir kütüğe \\
kaydetmeli, \\
- Kaydedilmiş videoyu JPEG veya AVI formatına \\
dönüştürmeyi desteklemelidir. \\
\end{tabular}

Canli izleme ve video oynatma için dijital zoom özelliğini desteklemeli,

- PTZ preset geri çağırma, pan (sağa sola hareket edebilme), tilt (aşağıyukarı hareket edebilme) kaydetme işlemleri dahil olmak üzere IP PTZ üzerinden sergileme yeteneğine sahip olmalı, - Yazılım, seçilen bir zaman aralığına ait hareket alarmlarını sergileme ve operatörü sesli ve görüntülü olarak ikazlama fonksiyonuna sahip

görüntüsünü ana monitörde göstermeye alarm kaydını bașlatabilmeli,

kaydettiği görüntüleri eşzamanlı olarak

tabanına belgelendirmeli,

Sürekli kayıt, kayıt kapalı, alarm/oy kaydı için özelliğini desteklemeli,

- Kaydedilmiş videoyu JPEG ve AVI formatlarına dönüştürmeyi desteklemeli,

Canlı erişim sağlayan entegre web hizmetin yetkileri tanımlama ve sifre ile erișim imkanına sahip olmal1,

kaydetmeli, dönüştürmeyi desteklemelidir.
Yazılım ve Kayıt Sistemi, H.264 ve MPEG-4 formatlarındaki görüntüleri kayıt edebilmeli,

- Yazılım ve Kayıt Sisteminin Full HD (1920x1080) kamera desteği bulunmal,bu destek ile yüksek çözünürlüklerde kayıt yapılabilmeli,

- Yazılım ve Kayıt Sistemi, Raid 5 ve Raid 6 desteğine sahip olmal1,

- Yazılım, canlı izleme ve video oynatma için dijital zoom özelliğini desteklemeli,

- Yazılım, sisteme bağlı tüm kameraların görüntüsünü gerçek zamanlı olarak ve kayıt üzerinden sergilemeli

- Yazılım, seçilen bir zaman aralığına ait olay/alarmların sorgulamasinı yapabilmeli,

- Yazılım, kameralar tarafindan tespit edilen hareket alarmlarınısergileme ve operatörü sesli ve görüntülü olarak ikazlama fonksiyonuna sahip olmal1,

- Yazılım, bir alarm/olay tetiklendiğinde, tetiklenmiş kanalın görüntüsünü ana monitörde göstermeye ayarlanabilmeli, - Yazılım, bir olay algilandıktan sonra pre-alarm ve post-alann kaydını başlatabilmeli,

- Yazılım, herhangi bir zamanda kameraların kaydettiği görüntüleri eşzamanlı olarak sergileyebilmeli,

- Yazılım, hızlı oynatma için alarm bildirimlerini veri tabanına belgelendirmeli,

- Yazılım, Sürekli kayıt, kayıt kapalı, alarm/olay kaydı için bir haftada saatlik bazda zamanlanmış kayıt özelliğini desteklemeli, sistem yazılımıakıllı hareket ya da obje algılama özelliğini destekleyen kameralarla birlikte kullanıldığında, belirlenen kurallara ya da filtrelere dayalı kayıt işlevini yerine getirebilmeli, - Yazılım, kaydedilmiş videoyu JPEG, MPEG veya AVI formatlarına dönüştürmeyi desteklemeli,

- Yazılım, canlı erişim sağlayan entegre web hizmetine sahip olmal1,

- Yazılım, değişik kullanıcı ve gruplar için erişim yetkileri tanımlama ve şifre ile erişim imkanına sahip olmalı,

- Yazılım, kullanıcıların eylemlerini bir kütüğe kaydetmeli,

- Yazılım, çözümlenen video akışlarını tek ya da çoklu monitörlerde gösterebilmeli,

- Yazılım, istemciler ile uzak aygıtlar arasında tam iki yönlü sesi desteklemeli,

- Yazılım, birden çok kameradan ses dâhil olmak üzere çeşitli biçimlerdeki videoyu dışa aktararak hızlı kanıt aktarımı sağlayabilmeli,

- Yazılım, video görüntülerinin görüntüleme ve kayıt parametrelerini ayarlama olanağına sahip olmalı,

- Yazılım, istenilen bir eylemin gerçekleştirilmesi için kamera sensor girişi, akıllı video hareket algılama, sistem alarmları veya mantıksal sensor girişi vb. durumları tetikleme olarak kullanabilmeli; tetikleme tiplerinin kullanılmasıyla kayıtlı adreslere e-posta gönderilmesi vb. aksiyonlar başlatabilmelidir.

Kaynak : 2 Aralık 2014 tarihli 29193 sayılı ve 31 Ocak 2015 tarihli ve 29253 sayılı Resmi Gazetede Yayımlanan Gümrük Yönetmelikleri

Yukarıda Tablo-2 ve Tablo-3'de görüldügü üzere 29253 sayılı ve 31 Ocak 2015 tarihli Resmi Gazete'de Gümrük Yönetmeliği'nde Değişiklik Yapılmasına Dair Yönetmelik yayımlanmıştır. Bununla birlikte bahsi geçen yönetmeliğin "Antrepolarda Bulunan Kamera 
Sistemleri” başlıklı 81/B no'lu ekinde değişiklik gerçekleştirilerek, özel antrepolara kurulacak kamera sistemlerinde aranacak bütün şartların genel antrepolara kurulacak kamera sistemlerinde aranan şartlarla aynı olması doğrultusunda düzenleme gerçekleştirilmiştir. Buna ilave olarak, antrepoda bulunan kapılar, antrepo sahası giriş-çıkış yerleri, eşya muayene alanları ve eşya girişçıkışına elverişli yerlerdeki kameraların "FULL HD" (1080P), diğer lokasyonlardaki kameraların "HD" (720P) olması ve sistem içerisinde kullanılacak olan kameraların "ONVIF Full Member" (Tam Üye) üyesi olması doğrultusunda düzenleme ve değişiklikler gerçekleştirilmiştir

Yönetmeliklerin içerik analizi sonucu 4 ana kategoride çıkarımlar yapılmıştır. $\mathrm{Bu}$ kategoriler; kör nokta kalmayacak şekilde kurulum, bir y1l geriye dönük kayıt, akı1lı video analiz ve alarm özelliği ve görüntü ile senkron ses kaydı başlıkları altında aşağıda izah edilmiştir.

\subsubsection{Kör Nokta Kalmayacak Şekilde Kurulum}

Antrepoda bulunan kapılar, antrepo sahası giriş-çıkış yerlerine, eşya giriş-çıkışına elverişli yerleri ile muayene ve elleçleme alanlarına, kameralar uygun şekilde konumlandırılmalı ve bu lokasyonlara konumlandırılacak kameraların saniyede en az 15 resim/kare (fps) görüntü oluşturacak ve 1080P çözünürlükte olacak şekilde temin edilmesi gereklidir. Buna ilave olarak antreponun açık alanı ile kapalı alanında genel denetim ve izleme sağlayacak şekilde de saniyede en az $10 \mathrm{resim} / \mathrm{kare}$ (fps) görüntü verecek ve en az 720P çözünürlükte olacak şekilde de kameraların konumlandırılması ile açık alanda kör nokta bulunmaması amaçlanmıştır. Bunun neticesinde tam kontrol sağlanabilecek, bütün lokasyonlar etkin bir şekilde izlenip, prosesler güvenle yürütülebilecektir.

\subsubsection{Bir Yıl Geriye Dönük Kayıt}

Antrepolarda konumlandırılmış olan kameraların her biri için, kayıt tarihi itibariyle kayıtların bir yıl boyunca arşivlenerek saklanması (dvd, harddisk, cd, bulut depolama vb.) ve kamera kayıtlarının depolanmasında minimum RAID 5 veya RAID 6 sistemi bulunması zorunluluğu ile geriye dönük izlenebilirlik imkânı oluşturulmuştur. Yönetmenliğine bakıldığında kamera kayıtlarının bir yıl saklı tutulması istenmektedir. Gerekli denetleme esnasında kayıtların depolanmasına ulaşılamaması halinde bakanlık gerekli cezaları uygulamaktadır. Yönetmenlik bir hafta geriye dönük yüksek çözünürlükte kayıtlar istenirken, kayıt yaşlandırma imkânı ile kayıtların çözünürlüğü düşürülerek RAID 5 veri güvenliği ile birlikte bir yıl boyunca sunucu üzerinden depolanma ve arşivlenme imkânı sağlayacaktır. Bu sayede gereken durumlarda geriye dönük incelemeler gerçekleştirilebilecek, olağandışı durumların tespiti yapılıp gerekli önlem ve uygulamalar hayata geçirilebilecektir.

\subsubsection{Akıllı Video Analiz ve Alarm Özelliği}

Yeni kamera yazılımı ile birlikte; tespit edilmiş bir zaman aralı̆̆ına ait alarmı/olayları sorgulaması, kameralar tarafından belirlenen hareket alarmlarını gösterme ve operatörü görüntülü ve sesli olarak ikaz ile uyarma fonksiyonuna sahip olması, bir alarm/olay oluştuğunda, tetiklenmiş kanalın görüntüsünü ana monitörde ekrandan göstermeye ayarlanabilmesi, bir olay algılanıp belirlendikten sonra pre-alarm ve post-alan kaydını başlatabilmesi ve buna ilave olarak akıllı hareket ya da obje algılama özelliğini destekleyen kameralarla beraber kullanıldığı zaman belirlenen kurallara ya da filtrelere dayalı kayıt özelliğini gerçekleştirebilmesi özellikleri ile güvenlik seviyesinin yükseltilmesi hedeflenmiştir. Yazılım, istenilen bir eylemin meydana getirilebilmesi için akıllı video hareket algılama, kamera sensör girişi, mantıksal sensör girişi veya sistem alarmları vb. durumları tetikleme aracı olarak kullanılabilecektir. Bu sayede olağandışı durumlarda önceden kayıt altına alınarak belirlenmiş e-posta adreslerine bilgi gönderilmesi vb. süreçler başlatılabilecek ve bu olağandışı durumlara müdahale etme şansı elde edilip güvenlik seviyesi üst seviyelere çıkarılabilecektir. 


\subsubsection{Görüntü ile Senkron Ses Kaydı}

Yönetmenlik kapsamında kameraların kullanım esnasında görüntü ile senkronize ses kaydı yapabilmesi gerekmektedir. Kameralar mikrofon vasıtasıyla dış ortamda bulunan sesleri operatöre iletme ve kayıt altında tutma özelliğine sahip olmalıdır. Bu sayede sadece görüntülere dayalı bir denetim olmayacak, seslerde kontrol ve gözetim altına alınarak olağandışı durumların tespiti ve akabinde müdahale şansı artacaktır.

\subsection{Mersin Gümrüklü Antrepocular Derneği ile Yapılan Derinlemesine Mülakat Sonucu Bulgular ve Değerlendirme}

Antrepoların büyük bir bölümünü üyeleri kanalıyla kapsayan Mersin Gümrüklü Antrepocular Derneği ile, gümrük mevzuatında yapılan değişiklikler birlikte uygulamaya konulması zorunlu olan teknolojik standartları ve güvenlik sağlama düzeyi yüksek kamera sistemi uygulaması ile ilgili olarak bilimsel araştırma yöntemlerinden nitel teknikler arasında yer alan derinlemesine mülakat yöntemiyle görüşmeler gerçekleştirilmiştir. Derinlemesine görüşme yapılandırılmamış görüşmedir ve standartlaştırılmamış, açık uçlu sorular sorulmaktadır (Puneh 2005: 167). Bu bağlamda çalışmada soru formu kullanılmamış ve konunun akışına istinaden açık uçlu sorular yöneltilmiştir. Bu sorulara örnek olarak; "Yeni kamera sistemlerinin antrepo sektörüne katkıları nelerdir?" "Yeni kamera sistemlerinin dış ticaret firmalarına etkileri neler olmuştur?" "Kamera sistemi kurulmasında karılaşılan teknik zorluklar nelerdir?" "Bu yeni uygulamanın maliyet yapısı ve işletmelere etkileri ne düzeyde gerçeklemiştir?" verilebilir. Derinlemesine görüşme, araştırmacının görüşme yaptığı kişiden aldığ 1 cevapları sınıflayarak konuyu mümkün olduğunca detaylı bir şekilde incelemeye çalıştı̆̆ 1 esnek ve keşfedici bir veri toplama tekniğidir (Tekin ve Tekin, 2012). Bu noktadan hareketle görüşmelerden sonra alınan cevaplar detaylı şekilde irdelenerek, genel olarak 3 ana kategoride sınıflanma gerçekleştirilmiştir. Bu kategoriler sistemin antrepo işletmelerine sağladığ faydalar, antrepo işletmelerine getirdiği dezavantajlar ve son olarak sistemin diş ticarete her yönüyle etkileri şeklindedir. Görüşmelerde ortaya çıkan bulgular aşağıdaki gibidir.

\subsubsection{Sistemin Antrepo İşletmelerine Sağladığı Faydalar}

- Özellikle mal kabul noktalarında güvenliğin artmış olması, sistemin genel itibariyle de kör nokta olmayacak şekilde projelendirilmesi ile hırsılılı, yolsuzluk vb. durumlarıyla karşılaşma şüphesi ve olasılıklarının önüne geçmeye katkı săgladığ1,

- Eski yönetmeliğe nazaran çözünürlüğü daha yüksek şekilde geriye dönük kayıt sorgulama imkânı bulunması noktasında hesap verilebilirliğinin ve olağandışı durumlarda inceleme yapılabilmesinin kolaylaşması,

- Her koşulda kameranın 7/24 kayıt etmesi ve aksi durumlarda, dışarıdan herhangi bir müdahale olması halinde ve sabotajlarda alarm üretip ilgili kişilere bildirim yapması ile birlikte kesintisiz bir güvenlik unsurunun ortaya çıkmış olması,

- Ekstra olarak, kamera sistemi uygulamasıyla 7/24 gözetim altında olması unsurunun işçilerin denetim altında tutuldukları konusuna katkı sağlamasıyla birlikte, iş güvenliği noktasında daha dikkatli ve verimli, çalışma noktasında ise daha performanslı çalışmaya dolayli yoldan destek vermesi,

- Genel itibariyle diş ticaret sektöründe faaliyet gösteren işletmelerin antrepo sektörüne duyduğu güvenlik seviyesinde artış sağlamış olması.

\subsubsection{Sistemin Antrepo İşletmelerine Getirdiği Dezavantajlar}

- Mali noktada mevzuatta yer alan kamera sistemi uygulamasının işletmelere kurulması bir külfet getirmiştir (antreponun büyüklüğüne göre ortalama olarak 60 bin USD ile 200 bin USD arasinda). 
- Söz konusu kamera sisteminin Türkiye'de temin edilememesi ve dişarıdan ithal gelmesi ve bu ithalatı gerçekleştiren çok sayıda firma olmaması fiyatların yüksek oluşuna sebebiyet vermiş ve kuruluş maliyetini artırmıştır.

- Sözü edilen maliyet artı̧̧1, sabit maliyetlerin doğrudan yükselmesine sebebiyet vermiştir.

- Sistemin kurulum esnasında istenilen unsurların tam verimle çalışma konumunun etkin bir noktaya gelme sürecinde ilk etapta bazı entegrasyonel ve teknik problemler yaşanmıştır.

\subsubsection{Antrepo Sektörü ve Genel İtibariyle Dış Ticarete Ektisi Yönüyle Değerlendirme}

Mersin Gümrüklü Antrepocular Derneği ile derinlemesine mülakat yöntemiyle gerçekleştirilen görüşmeler sonucunda; genel itibariyle tüm antrepo sektörüne katkısı noktasında antrepoların 7/24 kamera sistemleriyle gözetim altında tutulabilmesiyle olağandışı ve yasadış1 olayların önüne geçilmesine doğrudan destek verdiği, gerekli altyapıyı sağlayabilen hem genel hem de özel antrepo işletmeleriyle birlikte antrepo sektöründe bir kalite yükselmesi meydana geldiği, müşteriler ve satıcılar nezdinde önemli bir konumu bulunan antrepolara duyulan güven seviyesinin artışına sebebiyet verdiği görüş olarak belirtilmiştir. Ayrıca yeni kamera sistemi uygulaması ile birlikte antrepolara daha güvenli şekilde malzeme giriş çıkışının sağlanması yanında, antrepocuların maliyetini dolayısıyla da dış ticaret yapan firmaların maliyetlerini bir nebze yükseltmesi unsuru ortaya çıkmış olması hususu da yapılan derinlemesine görüşmede ortaya çıkan ve dikkat çeken unsurladır. Bu maliyet yükselmesi ile birlikte depo masraflarının diş ticaret yapan firmalara ve nihayetinde tüketicilere yansıması unsuru dezavantaj olarak görülmektedir. $\mathrm{Bu}$ dezavantajın yanında, sistemin diş ticarette çok önemli bir unsur olan güvenlik konusuna destek vermesiyle birlikte, diş ticaret sektöründe yer alan profesyonellerin veya profesyonel olma adaylarının, antrepo işlemlerindeki güvenlik algısına katkı sağlaması olumlu bir sonuç olacaktır. $\mathrm{Bu}$ durumunda doğrudan dış ticaret hacmine olumlu yansıyacağı düşünülmektedir. Yeni kamera sistemiyle birlikte antrepolarda yer alan ve özellikle yüksek maliyetli olan malzemelerin güvenle saklanması ve giriș çıkıșlarında güvenli aktarımına da yeni sistem katkı sağlamıștır. Ayrıca söz konusu sistem, yapılan her türlü çalışma ve her işte ilk olarak önemsenmesi ve göz önünde bulundurulması gereken unsur olan güvenlik unsurunu seviye olarak arttırmış olması yönüyle antrepolardaki üretim bazlı diğer işlemlere de sistemin daha güvenli işlemesi noktasında dolaylı olarak katkı sağlamıştır. Bu işlemler depolamanın yanı sıra ürünün özelliğini değiş̧irmeden basit imalat, ön/son montaj, bakım-onarım, mal bölme, sıralama, yeniden paketleme vb. işlemlerdir. Bu işlemler eskiye nazaran daha güvenli bir ortamda yapılabilme imkânına kavuşmuşlardır.

Son yıllarda Türkiye'de dıș ticaret potansiyelinin de hayli artmıș olması (Bkz. Tablo:4) nedeniyle bu alanda, sistemin etkin ve güvenli işlemesi için gerekli değişikliklerin yapılması zorunluluğu bulunmaktadır. Bu işlemlerin başında antrepolardaki yeni kamera sistemi uygulamaları gelmektedir. 
Tablo 4: Türkiye D1ş Ticaret İstatistikleri (2005-2018)

\begin{tabular}{lcccccc}
\hline & \multicolumn{2}{c}{ İhracat } & \multicolumn{2}{c}{ İthalat } & Diş ticaret dengesi & Diş ticaret hacmi \\
\hline Yllar & $\begin{array}{c}\text { Değer } \\
\text { (Bin \$) }\end{array}$ & $\begin{array}{c}\text { Değişim } \\
\mathbf{( \% )}\end{array}$ & $\begin{array}{c}\text { Değer } \\
\text { (Bin \$) }\end{array}$ & $\begin{array}{c}\text { Değişim } \\
\mathbf{( \% )}\end{array}$ & $\begin{array}{c}\text { Değer } \\
\text { (Bin \$) }\end{array}$ & $\begin{array}{c}\text { Değer } \\
\text { (Bin \$) }\end{array}$ \\
$\mathbf{2 0 0 5}$ & 73476408 & 16,3 & 116774151 & 19,7 & -43297743 & 190250559 \\
$\mathbf{2 0 0 6}$ & 85534676 & 16,4 & 139576174 & 19,5 & -54041499 & 225110850 \\
$\mathbf{2 0 0 7}$ & 107271750 & 25,4 & 170062715 & 21,8 & -62790965 & 277334464 \\
$\mathbf{2 0 0 8}$ & 132027196 & 23,1 & 201963574 & 18,8 & -69936378 & 333990770 \\
$\mathbf{2 0 0 9}$ & 102142613 & $-22,6$ & 140928421 & $-30,2$ & -38785809 & 243071034 \\
$\mathbf{2 0 1 0}$ & 113883219 & 11,5 & 185544332 & 31,7 & -71661113 & 299427551 \\
$\mathbf{2 0 1 1}$ & 134906869 & 18,5 & 240841676 & 29,8 & -105934807 & 375748545 \\
$\mathbf{2 0 1 2}$ & 152461737 & 13,0 & 236545141 & $-1,8$ & -84083404 & 389006877 \\
$\mathbf{2 0 1 3}$ & 151802637 & $-0,4$ & 251661250 & 6,4 & -99858613 & 403463887 \\
$\mathbf{2 0 1 4}$ & 157610158 & 3,8 & 242177117 & $-3,8$ & -84566959 & 399787275 \\
$\mathbf{2 0 1 5}$ & 143838871 & $-8,7$ & 207234359 & $-14,4$ & -63395487 & 351073230 \\
$\mathbf{2 0 1 6}$ & 142529584 & $-0,9$ & 198618235 & $-4,2$ & -56088651 & 341147819 \\
$\mathbf{2 0 1 7}$ & 156992940 & 10,1 & 233799651 & 17,7 & -76806711 & 390792592 \\
$\mathbf{2 0 1 8}$ & 167920613 & 7 & 223047094 & $-4,6$ & -55126481 & 390967707 \\
\hline
\end{tabular}

Yukarıda Tablo-4'de görüleceği üzere Türkiye'nin dış ticareti son yıllarda çok büyük oranda (2005 ile 2018 yılları arasında toplam dış ticaret artışı yaklaşık 200 milyar dolar) artmıştır. Bu noktada dış ticaret sisteminin etkin ve güvenli işlemesi için yapılması gerekli uygulamalardan biri, sistemde önemli bir konumu olan antrepoların güvenli şekilde yönetilmesine destek sağlayan kamera sistemleridir.

Ayrıca gümrük kontrolleri sonucu yakalamalar da değer olarak büyüklüğü azımsanmayacak düzeydedir. $\mathrm{Bu}$ noktadan bakıldığında yine antrepolardaki yeni kamera sistemlerinin genel olarak sistemin güvenli işleyişine destek vereceği rahatlıkla değerlendirilebilir.

Tablo 5: Gümrük Kontrolleri Sonucu Eşya Grupları Bazında Yakalama İstatistikleri Yakalamalar (Değer: TL)

\begin{tabular}{ccccc}
\hline Eşya Grupları & $\mathbf{2 0 1 5}$ & $\mathbf{2 0 1 6}$ & $\mathbf{2 0 1 7}$ & $\mathbf{2 0 1 8}$ \\
\hline Uyuşturucu & 206.774 .451 & 236.110 .652 & 892.512 .877 & 1.320 .771 .681 \\
Çeşitli Eşyalar & 244.656 .092 & 454.692 .414 & 340.262 .476 & 476.733 .609 \\
Araç & 88.584 .836 & 177.113 .552 & 503.147 .910 & 298.861 .741 \\
Tütün Ve Alkol & 102.470 .171 & 113.055 .453 & 141.601 .271 & 168.202 .878 \\
Makine Ve Aksamı & 585.948 .984 & 306.742 .283 & 38.030 .109 & 162.100 .371 \\
Tekstil & 160.079 .612 & 686.774 .951 & 85.402 .567 & 149.060 .588 \\
Gıda & 30.211 .424 & 207.508 .230 & 169.862 .398 & 148.168 .843 \\
Elektronik Eşya & 255.752 .635 & 62.017 .076 & 65.938 .720 & 134.316 .998 \\
Tibbi Eşya & 50.662 .118 & 43.663 .534 & 69.503 .750 & 55.571 .303 \\
Döviz & 781.132 & 15.633 .661 & 16.775 .571 & 46.794 .210 \\
Değerli Maden & 16.554 .826 & 38.499 .540 & 17.662 .626 & 37.932 .587 \\
Akaryakıt & 824.791 .954 & 281.048 .074 & 182.050 .130 & 19.367 .322 \\
Zirai & 2.859 .586 & 3.222 .304 & 7.453 .112 & 10.717 .788 \\
Silah Ve Mühimmat & 8.675 .441 & 1.020 .844 & 2.388 .280 & 3.365 .897 \\
Kimyevi Madde & 6.837 .565 & 5.650 .860 & 3.098 .956 & 2.474 .435 \\
Tarihi Eser & 96.311 .041 & 71.440 & 13.156 & 38.664 \\
Sahte Belge & 5.847 .511 & 162.018 & 844.897 & 1.625 \\
Nükleer Madde & - & - & - & - \\
\hline TOPLAM DEĞGR & $\mathbf{2 . 6 8 7 . 7 9 9 . 3 7 9}$ & $\mathbf{2 . 6 3 2 . 9 8 6 . 8 8 5}$ & $\mathbf{2 . 5 3 6 . 5 4 8 . 8 0 6}$ & $\mathbf{3 . 0 3 4 . 4 8 0 . 5 4 0}$
\end{tabular}

Kaynak : Türkiye Risk Yönetimi ve Kontrol Genel Müdürlüğü, Erişim Tarihi : 01-02-2020

Yukarıda Tablo-5'de görüldügü üzere ortalama olarak gümrük kontrolleri sonucu yasadış1 yakalanan tutar miktarı 3 milyar TL civarında olup, bu tutar hiç de azımsanmayacak düzeydedir. 


\section{Genel Değerlendirme ve Sonuçlar}

Dış ticarette antrepo rejimi; üreticiden tüketiciye malzeme akışında konum itibariyle, ithalatta istenildiği zaman malzemelerin çekişine izin vermesi ve dolayısıyla vergilerin istenildiği anda ödenmesine firsat vermesiyle mali noktada, müşteriye malzeme akışında ise depo faaliyetinin gerçekleşmesine olanak tanımasıyla lojistik faaliyetine destek noktasında, depolamanın yanı sıra ürünün özelliğini değiştirmeden basit îmalat, ön/son montaj, bakım-onarım, mal bölme, sıralama, yeniden paketleme vb. işlemler yapılabilir olmasıyla da üretime destek olmasılyla önemi yüksek mahiyettedir. $\mathrm{Bu}$ işlemler gerçekleşirken yasa dışı işlemler, kaçak ürünler, hırsızlık vb. olayların olmasını engellemesi bağlamında güvenlik sağlama çabaları ve işlemlerine yüksek oranda önem verilmesi gerekliliği aşikârdır. Bu noktada kamera sistemlerinin konumu özenle değerlendirilmesi gereken bir konudur.

Türkiye'de antrepolarda kamera sistemleri konusunda gerekli hassasiyet son y1llarda Gümrük yönetmeliğiyle yapılan değişiklikler ile gösterilmiş ve gerekli sistem kurulumları hızla gerçekleştirilmiştir. Genel itibariyle, kamera sistemleri ile ilgili güncel gümrük mevzuatı yönetmeliklerine yapılan içerik analizi sonucu ve ayrıca derinlemesine mülakat yöntemiyle görüşme gerçekleştirilen Mersin Gümrüklü Antrepocular Derneği'nden alınan bilgilerden yola çıkılarak, sözkonusu kamera sistemi uygulamasının güvenliğe yüksek oranda destek verdiği rahatlıkla söylenebilir. Sistemin dikkat çeken özellikleri; kör nokta kalmayacak şekilde kurulum gerektirmesi ve kritik noktalarda FULL HD (1080P) kamera ve diğer lokasyonlarada en az HD (720P) özellikte kamera ile yüksek kalite görüntü elde etme ile denetim imkanı sağlaması, bir yıl geriye dönük kayıt özelliği ile geriye dönük izlenebilirlilik sağlaması, akıllı video analiz ve alarm özelliği ile videoların istenilen kriterlerde analiz edilebilmesi ve olağandışı durumlar için alarm özelliği sağlayabilmesi, ve görüntü ile senkron ses kaydı özelliğiyle sadece görüntülere değil seslere bağl1 da kontrol sağlanabilmesi şeklindedir.

Sistemin tek dezavantajı kamera sisteminin antrepo işletmesine kurulum maliyeti olarak görülmektedir. Bu unsur doğrudan maliyet artışına sebebiyet vermesi yönüyle ilk olarak dış ticaret şirketlerine, dış ticaret şirketlerinden de müşterilerine yansıyacaktır. Lakin Türkiye'nin son yıllarda dış ticaret hacminin çok büyük oranda artmış olması hususu göz önüne alındığında, kaliteli ve güvenli bir antrepo sistemin gerekliliği elzem konuma yükselmiştir. Dolayısıyla atılan söz konusu bu adım, geleceğe yönelik olarak antrepolar için büyük bir güvenlik teminatı olması yönüyle çok önemli konumdadır. Literatürde bu konuda antrepolar sektöründe kamera sistemleri ile ilgili çalışmaya rastlanmaması itibariyle, bu çalışma literatüre katkı sağlayacaktır. Dış ticaret sektöründe faaliyet gösteren işletmelere ve işletme adaylarına ise, çalışmamızda sözkonusu sistemin fayda, dezavantaj ve dış ticarete etkileri yönünde bilgi verilmesi hasebiyle katkı sağlayacaktır. Bu bilgiler ışığında sözkonusu işletmeler dış ticaret operasyonlarını zaman, maliyet vb. kriterler bazında daha verimli yürütebilme imkânına sahip olabileceklerdir. Gelecekteki çalışmaların antrepolardaki kamera sistemleri haricinde gerçekleşen güvenlik unsurlarını incelemeleri, konunun daha derinlemesine analizine imkân sağlayabilecektir.

\section{Kaynakça}

Acar, Z.A. \& Çakmak, E. (2013). Depolama ve depo yönetimi. Nobel Yayıncılık.

Ak, M. (2019). Organizational climate analysis in the foreign trade sector. Nobel Yayınc1lik.

Bilgin, N. (2014). Sosyal bilimlerde içerik analizi. Siyasal Yayınevi.

Coşgun, K.Ö. (2011). Gümrük antrepoları, eşyanın tasfiyesi ve antrepo ücretinden sorumluluk. Marmara Üniversitesi Hukuk Fakültesi Hukuk Araştırmaları Dergisi, 17(1-2), 377-392.

Gökçe, O. (2019). Klasik ve nitel içerik analizi. Çizgi Yayınevi. 
Guangming W. (2016,May 14-15). Build cross-border e-commerce overseas warehouseplatform effectively [Conference presentation]. 2nd International Conference on Social Science and Technology Education. Guangzhou, China.https://doi.org/10.2991/icsste-16.2016.74

Gürbüz, S. \& Şahin, F. (2018). Sosyal bilimlerde araştırma yöntemleri. Seçkin Yayıncılık.

Holstein A. J. \& Gubrium, J.F. (2004).The active interview, qualitative research theory method and practice. Sage Publications.

Hopbaoğlu, F. (2009). Tedarik zincirinde ve lojistik süreçlerde depo tasarımı ve depo yönetimi: Kozmetik sektöründe bir uygulama [Yüksek lisans tezi]. İstanbul Teknik Üniversitesi Fen Bilimleri Enstitüsü.

Koban, E. \& Yıldııı, H. K. (2007).Dış ticarette lojistik. Ekin Basım Yayın Dağııım

Milli Eğitim Bakanlığı (MEB). (2011). Ulaştırma hizmetleri: Antrepo.MEB Yayınları.

Özeroğlu, A.İ. (2011). Diş ticaret ve antrepo rejimi. Anadolu BİL Meslek Yüksekokulu Dergisi, 6(22), 32-36.

Park, J. S., Chang, Y. S., Jung, S. H., Son, M. G., Yang, J. H., \& Kim, T. H. (2008, July 6-8). Study of RFID based bonded warehouse process [Conference presentation]. 13th International Symposium on Logistics Integrating the Global Supply Chain. Bangkok, Thailand.

Richards, G. (2017). Warehouse management: A complete guide to improving efficiency and minimizing costs in the modern warehouse. Kogan Page Publishers.

Subaşı, M. A. (2009).Gümrük işlemlerinin lojistik maliyetlere etkisi [Yüksek lisans tezi]. Marmara Üniversitesi Sosyal Bilimler Enstitüsü.

Tanyaş, M., \& Baskak, M. (2012, Mayıs 10-12). Farklı açılardan depoların sınıflandırması [Konferans sunumu].Ulusal Lojistik ve Tedarik Zinciri Kongresi. Konya, Türkiye.

T.C. Ticaret Bakanlığı Risk Yönetimi ve Kontrol Genel müdürlüğü, 2020, risk.gtb.gov.tr, Erişim tarihi: 01.02.2020

T.C. Ticaret Bakanlığı Gümrükler Genel Müdürlüğü, ggm.gtb.gov.tr, 2019, Erişim tarihi:14.8.2019

Tekin, H. \& Tekin, H. (2012). Nitel araştırma yönteminin bir veri toplama tekniği olarak derinlemesine görüşme.İstanbul Üniversitesi Sosyoloji Dergisi, 3 (13), 101-116.

Tompkins, J.A. \& Smith, J.D. (1998). The Warehouse management handbook. Tompkins Press.

TUIK (Türkiye İstatistik Kurumu), 2020, www.tuik.gov.tr. Erişim tarihi: 01.2.2020

Varol, N. B. (2009). Dış ticaret işletmelerinde lojistik uygulamalar açısından depo ve antrepo yönetimi [Yüksek lisans tezi]. Marmara Üniversitesi Sosyal Bilimler Enstitüsü.

2 Aralık 2014 tarihli 29193 sayılı Resmi Gazete Gümrük Yönetmeliği’nde Değişiklik Yapılmasına Dair Yönetmelikte ek-81/B, Erişim tarihi: 01.2.2020

31 Ocak 2015 tarihli ve 29253 sayılı Resmi Gazete Gümrük Yönetmeliği’nde Değişiklik Yapılmasına Dair Yönetmelikte ek-81/B, Erişim tarihi: 01.2.2020 